\title{
Research and Practice on Construction of "First Class Specialty" in Private Colleges and Universities
}

\author{
Ma Lijuan \\ Engineering Institute \\ XI'AN International University, \\ XI’AN, 710077, China
}

\begin{abstract}
With the development of higher education from elite education to mass education, the ranks of private colleges and universities have gradually developed and expanded. From the initial supplementary status for higher education, they are turning to an important part of undergraduate education, how to improve the teaching quality and give full play to its unique social service function has become the primary task of private undergraduate colleges and universities. This study begins with the analysis of the basic situation of the first-class professional construction of private undergraduate universities, summarizes the construction experience, objectively evaluates the problems existing in the first-class professional construction of private undergraduate universities, and scientifically analyzes the factors that affect and restrict their development. Finally, the countermeasures and suggestions of the first-class professional construction of private undergraduate universities are put forward.
\end{abstract}

Keywords-Private colleges and universities; First-class specialty; Applied; School orientation

\section{INTRODUCTION}

According to the statistics of the national bureau of statistics of the People's Republic of China, there were 2,560 regular institutions of higher learning in China in 2015, of which 734 were private institutions of higher learning. In 2016 , there were 2,596 regular institutions of higher learning in China, including 741 private ones. In 2017, there were 2,914 regular institutions of higher learning, including 746 private ones. As of May 31, 2018, there are 2,914 institutions of higher learning in China, including 2,631 ordinary institutions of higher learning (including 265 independent colleges) and 283 adult institutions of higher learning. In the "List of National Colleges and Universities" announced by the Ministry of Education on June 14, 2018, there are a total of 1,243 undergraduate colleges and universities in the country, of which there are 817 public undergraduate universities, and a total of 735 private colleges and universities recognized by the state. There are 417 private undergraduate schools. It can be seen that the proportion of private undergraduate colleges and universities in the National undergraduate colleges is very high, and it plays a pivotal role in the development of Chinese undergraduate colleges and universities. It has made important contributions to the development of regional economic development for China's higher education from elite education

Fund Project: 2017 schooleducation and teaching reform project" Research and practice of "first-class professional" construction in private universities" (fund number: 2017B28) to popular education.

Private colleges and universities show an increasing trend from 2010 to 2014, the figure can be seen after 2015, the number of private colleges tends to be stable, the number of private colleges in 2018 reduced to 735 from 746 in 2017, It shows that in the process of the development of private colleges and universities, it has entered the period of winning the fittest, how to survive in such an environment is an urgent task for private colleges and universities. By the end of 2015, the state council formally issued "overall plan for the construction of world-class universities and top disciplines”, it set off a new storm for the development of higher education and also pointed out the direction for private undergraduate colleges and universities, it is to improve the quality of education, take the first-class professional construction as an opportunity to develop professional characteristics and improve the competitiveness of private undergraduate institutions.

\section{THE CONSTRUCTION STATUS OF PRIVATE COLLEGES AND} UNIVERSITIES

\section{A. Deep-rooted traditional attitudes lead to low levels of social acceptance.}

Firstly, under the influence of traditional concept of "academic inheritance"[1], education in China pays more attention to the teaching of theoretical knowledge and neglects the cultivation of practical ability, students and parents are more satisfied with education examination. Secondly, with the continuous improvement of living standards, people pay more and more attention to education, which also leads the educatees to pursue higher education. In the selection of schools, 985 and 211 universities are the first, followed by public institutions, and finally private institutions are considered. Finally, employers tend to be serious about the nature of colleges and universities when recruiting talents and they only pay attention to the level of graduate schools instead of the characteristics of positions in human resources.

\section{B. The uniqueness of evaluation mechanism leads to the homogeneity of professional construction}

At present, the ranking indexes of colleges and universities mainly measure schools from the number of key disciplines, awards of scientific research achievements, doctoral points and so on, but not according to the quality of student training, 
social acceptance and other aspects of the evaluation criteria, leading to all schools in accordance with a standard to build, making schools pay more attention to these indicators in the construction. In fact, the assessment of these indicators means the assessment of teacher's scientific research ability. However, there are no corresponding standards to measure the quality of students' training. As a result, professional construction can not be based on the school level, social service functions to establish the direction of construction.

\section{Insufficient funding makes teaching quality difficult to improve}

Public institutions of higher learning receive state funding while charging tuition fees, but there is no state funding for private colleges. Main funding comes from the students pay cost, number of students is the important factor of school survival. Which decides the school students in bad grades when recruit students. The students who meet the minimum scores are usually enrolled in private colleges. In the external environment where the number of students in the college entrance examination is greatly reduced and the public universities are vigorously expanding their enrollment, the phenomenon that private colleges and universities scramble for students will inevitably lead to poor quality of private college students. In the teaching link, no matter how many mistakes students make, they try not to deal with them, so that students think they can pass without learning, which forms a vicious circle and makes it difficult to improve the teaching quality.

III. ANALYSIS OF FACTORS RESTRICTING THE CONSTRUCTION OF FIRST-CLASS MAJORS IN PRIVATE COLLEGES AND UNIVERSITIES

\section{A. School orientation tends to homogeneity}

"Homogenization"[3] means that under the influence of external development, many individuals with different characteristics change their internal characteristics, and the result of this characteristic change is similar. This phenomenon is reflected in the orientation of higher education in today's higher education. It does not distinguish between school levels and students, and it pursues academic education in a unified manner. It is also uniform in professional settings. Due to the differences in student sources, students cannot adapt to the curriculum, which results in the immobility of teachers, immobility of students and low teaching quality. Xiao jianle and sun dehua[6] pointed out that at present many college professional training objectives are set on the high side in our country, the curriculum is theorized and westernization, vague personnel training goals, teaching methods are still focused on imparting knowledge, ignore the skills training, single education pattern, can't take the corresponding differential education according to the characteristics of the students, leading to develop talent is difficult to quickly adapt to the development of the society. Lin hong and yaoyun (2009) believe that the main cause of structural unemployment is the disconnection between professional setting and social needs, following the trend of copying, lack of characteristics of professional setting, and cannot be combined with local industrial structure and economic development. Yinxiaomin (2016) pointed out that the development goals of most private colleges and universities are not clear, the orientation of running a school is uncertain, and the extended development is carried out in an inertial way, regardless of the history, comprehensive strength and cultural accumulation of running a school. The educational goal is unrealistic, pursues the comprehensive discipline specialized establishment, pays attention to the teacher high professional title. It is impossible to determine whether the educational goal is an academic university or a technical university, which makes the graduate students lack both theoretical and practical ability. Aiming at the elite education teaching model, it shows the trend of imitating the comprehensive university or even the first-class university.

\section{B. Professional Settings go with the tide and lack of accumulation}

At present, many private colleges and universities have a serious tendency to go with the tide when setting their majors. The school did not carry out sufficient market research, demand forecasting and expert argumentation process. If majors are popular, they will be opened, and if majors are not popular, they will be closed. The construction process of majors cannot be continuous, so it cannot be accumulated or form a long-term and continuous overall plan. Therefore, it is difficult for majors to be built up and to form their own professional characteristics.

\section{Teacher evaluation mechanism is not balanced with training objectives}

In personnel training goal: to master the professional basic theory, professional knowledge, can apply theory to analyze problems, troubleshooting, and ability to provide a solution, has engaged in this professional maintenance, operation, troubleshooting and other work skills and preliminary development under the premise of the design level, it must need to have theoretical knowledge and rich practical experience of teachers to match. However, the current teacher evaluation mechanism focuses more on the quantity and quality of scientific research papers. Although willing to recruit double teachers, also has the corresponding engineer title evaluation system, But in the actual process of teaching and examination, assessment of schools still use the same way, there is no corresponding practice ability appraisal way, forcing engineering series of teachers must also published an article, cannot ascend into their practice ability, at the same time also cannot give full play to their practical experience in teaching link of the teaching effect.

\section{Mismatch between curriculum system construction and industry docking}

The curriculum system can reflect whether the professional structure is reasonable, whether the training objectives are clear, whether the professional characteristics are prominent and so on. Therefore, the construction of the curriculum system is an important part of professional development. However, the current private university curriculum system generally has the following problems: Firstly, they lack the 
investigation and analysis on the construction of curriculum system, copy the curriculum system of research universities blindly, so that most private universities hold the title of application-oriented undergraduate universities, but implement the "academic" curriculum system, deviating from the application-oriented private colleges and universities should serve the local needs, the direction of running schools should meet the market demand. Secondly, the "academic" curriculum system adopted in the curriculum system, and considering the "application" and the level of students, will inevitably lead to confusion in the curriculum structure, theoretical knowledge learning is not enough, the embarrassing situation of inadequate practical ability. Thirdly, the content of the course is influenced by the academic teaching mode, which emphasizes the systematicness and completeness of the subject knowledge, and does not start from the post ability training, which leads to the mismatch of the industry docking.

\section{E. The cooperation between the school and the enterprise stays on the surface}

The cooperation between the school and the enterprise is the best way to realize post capacity training and teaching process to excessive production process. However, due to the differences of interests, concerns and operating mechanism between the two sides, the cooperation between private colleges and enterprises is generally on the surface, and the substantive cooperation is not much, nor can it form a longterm and sustainable cooperation. Generally, schools are active in contacting enterprises and seeking ways and means of cooperation. However, enterprises are reluctant to spend too much time and energy on personnel training because of their pursuit of self-interest and more attention to efficient ways of making profits. Therefore, after signing a cooperation agreement, enterprises are often in a state of negative coping and perfunctory.

\section{STRATEGIES FOR BUILDING A FIRST-CLASS PROFESSIONAL IN PRIVATE UNIVERSITIES}

\section{A. Accurate positioning is the basis for the first-class professional development}

Minister of Education Student Secretary Juzhenyuan[4] said: "As the main body of cultivating students, universities must face the society, face the market, adjust independently, and integrate well with the future employment situation. In teaching, they should integrate short-term and long-term needs, basic and applied requirements, humanities and science education requirements, academic and vocational skills training. All of these need to be unified and seriously studied. Every university must have its own accurate positioning, all academic is definitely not". Therefore, colleges and universities at different levels should have a clear positioning for themselves in line with the actual needs of society, achieve dislocation development, and form a multi-level complementary form. Social needs for talents include: Advanced academic talents, applied talents, technical talents and service oriented talents. The training of talents in universities should be to train advanced academic talents or applied talents. However, according to the conditions of running private colleges and universities and the characteristics of students, the orientation of running private colleges and universities should be oriented to training applied talents. And applied talents should also be divided into development and design talents and technical support talents. After the transition from elite education to mass education in universities, many ordinary public colleges and universities also define the goal of training talents as the training of applied talents[2].The purpose of education is to target the educated. The goal of training is to target specific educational subjects. The educational objects of all levels and types of schools have different characteristics. Therefore, the characteristics of students in each school must be taken into account in formulating the training objectives. According to the characteristics of students, teachers and hardware input of private colleges and universities, private colleges and universities should orientate the training objectives of application-oriented talents to technical support-oriented talents training more accurately, so as to define the training objectives more specifically as follows: Master the basic theory and professional knowledge of the profession, can apply the theoretical knowledge to analyze problems, troubleshoot, provide solutions, have the skills to engage in the professional maintenance, operation, fault detection and other work skills and initial development and design level.

Academic talents are mainly engaged in researching and discovering objective laws, solving major social problems or formulating management systems. In the process of training, we need to study and explore the theoretical knowledge deeply, and they are in the leading position at the top of the pyramid in the social needs, and they need less. Application-oriented talents include design-oriented talents and technical talents, development-oriented talents pay attention to demand analysis, development and design ability training, so need to have a solid theoretical foundation, can develop and design products according to customer needs. Technical talents pay attention to cultivating the ability to solve practical problems and troubleshoot and assist designers to complete products. Therefore, it is necessary to stress the theoretical knowledge in the process of training, cultivate the ability to handle and solve problems on the spot with professional technical knowledge, possess the management technology of manpower operation research, and have a strong organization for equipment operation. Coordination and operation ability. From the talent structure and demand diagram, it can be seen that technical talents play a bridge role in transforming design and decisionmaking into products and implementation plans. Skilled talents rely on operational skills to complete on-the-spot production, do not need too much innovation and design, mostly deal with repetitive labor, in the talent structure and demand diagram at the bottom of the social labor chain, belong to labor-intensive, actual labor demand is the most demanded.

\section{B. Guided by market demand is the basis for first-class professional development}

Specialty construction should serve the development of regional economy and meet the needs of talent structure and 
society. Therefore, in the process of specialty construction, we should fully investigate and analyze the characteristics of regional economy and the demand of labor market. From the goal of talent cultivation to the construction of teaching staff, from the teaching content to the teaching mode to the formulation of teaching methods, we should take the market demand as the guide to revise. In designing and planning the specialty construction, we should also make the specialty construction adjustable. We should constantly develop teaching contents and teaching methods to meet the market and social needs. We should train talented people to meet the needs of society, to meet the smooth export of talented people and the accurate introduction of social demand for talented people, so as to meet the export of talented people and the introduction of two-way needs of the two markets, to achieve a win-win situation.

\section{The construction of teaching staff is the key to the construction of first class majors}

In the construction of Applied Undergraduate universities, the ranks of teachers must also conform to the orientation of running a school. Therefore, the key to the first-class professional construction is to build the ranks of "dualqualified teachers". Firstly, we should establish and perfect the evaluation index system of "dual-qualified" teachers, and formulate the matching methods of appointment, assessment, award and promotion, so as to provide a growth environment for "dual-qualified" teachers. Secondly, to provide training opportunities for existing professional teachers, the introduction of appropriate policies and funds, to encourage teachers to enter the enterprise suspension exercise, rotational work and other forms of participation in the production practice of enterprises to achieve the upgrading of teacher's professional skills and practical ability. Finally, the introduction of enterprise professionals and technicians to join the teaching team, participate in the teaching link design, curriculum design and other work, for professional construction to grasp the direction of the industry, this must be based on the introduction of the corresponding salary incentive system as a prerequisite.

\section{Curriculum system construction is the core of first-class professional development}

At present, there are many problems in the curriculum system, such as the disconnection between curriculum content and vocational ability, the obvious tendency of learning and so on. Therefore, in the process of specialty adjustment and optimization, we should fully analyze the specific requirements of talent market, profession and post in accordance with the needs of regional economic and social development, relying on enterprises, institutions and industries, and then formulate professional planning and determine the curriculum system. In the construction of curriculum system, the post requirements should be taken as the goal, the curriculum should adopt modular teaching, and the gradual progress of each semester should be related, not independent. Constituting the curriculum system to achieve the project, the completion of each project will achieve the post requirements of a capacity, which is based on the work process of training model, is in line with the professional construction curriculum system.

At the same time, we should perfect the project module syllabus; establish the corresponding assessment methods, teaching documents and so on. Strengthen cooperation between schools and enterprises, develop a project-based curriculum system combining production processes, and constantly improve practical teaching materials, courseware and standardized processes. The curriculum system should grasp the characteristics of vocational posts and sort out the core backbone courses. On the premise of taking the backbone courses as the center, it has the characteristics of adjusting with the development of economy and society, meeting the law of market change and the change of market demand.

\section{E. School enterprise cooperation is a means of first-class professional development}

In order to realize the deep integration and long-term development of school-enterprise cooperation, the premise of cooperation must be the realization of "win-win" between schools and enterprises. On the one hand, enterprises help schools to cultivate professional counterparts, highly skilled and highly qualified applied talents. On the other hand, schools should give full play to their own professional and technological advantages in accordance with the principle of serving regional economic construction, and actively help enterprises to solve product research and development, technological problems, or provide some resource sharing mechanism to provide practical and effective help for enterprises. Only in such a mutually beneficial mode can school-enterprise cooperation be carried out effectively, not superficially, and promote the long-term effective and sustainable development of school-enterprise cooperation.

\section{CONCLUSION}

To sum up, the construction of "first-class majors" [1] in private colleges and universities is related to the development direction of private colleges and universities, and is the key to stand out in the fierce competition today. Private colleges and universities should seize the historical opportunity, accurately grasp the direction, follow the characteristics of private colleges and universities, carry out the innovation and exploration of personnel training mode, professional construction and curriculum system, and actively improve the reform of organization, management system and evaluation mechanism, so as to realize the promotion of the level of private colleges and universities and highlight the people. The characteristics of running colleges and universities.

\section{REFERENCES}

[1] Yin Xiaomin. Applied development of private undergraduate universities: foundation, challenges and strategies [J]. Journal of Shuren University, Zhejiang.2016 (6) :8-13

[2] Yuan Wen. Building a first-class Open University with Chinese characteristics: goal connotation and action strategy [J].Open Education Research, 2018 (3) :12-18 
[3] Liu Guoyu. The construction of world class discipline: from the perspective of integration of academic and practical [J].Modem education management, 2018 (5) :19:23

[4] Lv Linhai and Gong Fang. A comparative study of deep learning and its influencing mechanism between Chinese and American undergraduates in Research Universities [J].Education Research , 2018 (4) :111-120
[5] Xu Dehua. Professional development of first class teachers in the training of top notch English talents [J].Education and occupation.2013(23).79-80

[6] Xiao Jianle, Sun Dehua. Some thoughts on the training mode of Chinese Higher Education[J]. Fujian Forum, 2009 (10) :117-118 